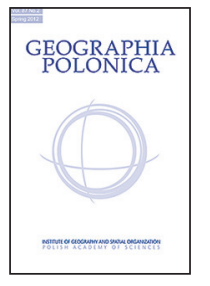

\title{
CULTURAL INTEGRATION: POSITIVE AND NEGATIVE PERCEPTIONS (CASE OF TORNIO, FINLAND)
}

\author{
Ekaterina A. Shlapeko - Svetlana V. Stepanova \\ Institute of Economics \\ Karelian Research Center of the Russian Academy of Sciences \\ 50 A. Nevskogo st., Petrozavodsk 185030, Republic of Karelia: Russia \\ e-mails: shlapeko_kate@mail.ru • svkorka@mail.ru
}

\begin{abstract}
Increase in the migration flows has become a challenge in the world today. In Finland there is considerable shift in the number of migrants from Africa and the Middle East countries. The paper is based on the sociological research conducted in August-September, 2016 in Tornio (Finland). The empirical observations were gained from the interviews with 12 migrants and the questionnaires on the city Tornio attractiveness (73 locals) and the human mobility challenges ( 89 locals). The obtained results highlight the significant role of the communication activities with the joint participation of locals and newcomers in understanding each others' culture, decreasing negative perceptions and reactions in the integration process.
\end{abstract}

\section{Key words}

cultural integration $\bullet$ migration $\bullet$ newcomer $\bullet$ asylum seeker $\bullet$ host community $\bullet$ Tornio

\section{Introduction}

Today the world observes both integration and disintegration processes followed by the interference and interaction of cultures. The relevance of studying multiculturalism in the European cities is also caused by the modern challenges, such as, immigration and the inflow of refugees. The migration is not a new phenomenon for Europe. It became a destination of significant migratory flows in the last few decades. Within the European Union (EU), nearly 20 million residents (or 4\%) are non-EU citizens and in 2015 more than
1.2 million people applied for the asylum in the EU (Migration integration statistics). The unstable social, economic and political conditions, military operations in Africa and the Middle East along with the favorable living conditions, demand for the labor and the problems with an aging population provoked a strong flow of those who wish to come to Europe and become the European citizens.

The migration flows not only identify the issue of the trans-border mobility, but also the important social and cultural characteristics of the community as a whole. This brings another new cultural and spiritual value com- 
ponent that could change the existing social, cultural and psychological attitudes in the local community (Joppke 2012; Solodova \& Gomzova 2013). The states and citizens are showing contrasting reactions to the refugee challenges and after crossing physical borders, immigrants are faced with many other, invisible borders (Löf 2016). Most refugees in Europe come from the nations that are predominantly Muslim. It is difficult these days to use the words "Arab" or "Muslim" without thinking of the Islamic extremists, in part due to the media-supported link between Islam and terrorism (Wekhian 2016). Moreover, as a Pew Research Center survey illustrates, the refugee crisis and the threat of terrorism are very much related to one another in the minds of many Europeans (PRC 2016). In every country polled, the dominant view is that Muslims want to be distinct from the rest of society rather than adopt the nation's customs and way of life. Is it possible to achieve harmonious integration of Afro-Arab immigrants into the European Community?

In 2015, Finland was among the top ten EU countries with regard to the number of asylum-seeker applications (Number of (non-EU) asylum seekers 2015). During that year, the highest number of asylum seekers $(32,476)$ arrived to the country, mainly from Iraq $(20,485)$, Afghanistan $(5,214)$ and Somalia $(1,981)$ (Asylum seeker... 2016; Annual report 2015; Number of asylum... 2015; Population. Statistics Finland). According to the Finnish Immigration Service the highest number of asylum seekers arrived to the country at the end of September during week 39: 3,939 persons. On 31 December, 2015 in Finland, there were 144 units of Reception centers for the adults and the families and 68 units for unaccompanied minors (Annual Report 2015; EMN 2017). According to interviews of asylum seekers the migration route takes 30-45 days and runs from Turkey through Greece, Macedonia, Serbia, Hungary, Austria, Germany, Denmark, Sweden and finally via Lapland to Finland. The interviewed asylum seekers mentioned the following reasons for choosing a sparsely-populated country on Europe's northern frontier: (1) far from the conflict areas, (2) the high standards of the living and the generous social benefits and (3) the tolerance and the refugee-friendly attitude. The social media and the immigrant networks played an important role in disseminating the desirability of Scandinavia as an asylum destination (Tanner 2016). Some 15,000 asylum seekers had registered at the Tornio border's reception centre by December 2015 (Asylum seeker 2016). In September the fifth registration centre was opened in Tornio (Annual Report 2015; Registration centre 2015). What is the reaction of native citizens to the newcomers? What did both sides expect and how did it turn out in reality? Thus, the key challenge for current governments is to ensure the integration of a large number of people for future smart, sustainable and inclusive territorial development.

This article will attempt to demonstrate the dependence of the relations between the asylum seekers and the host community on the knowledge of the behavior patterns. By the examining life styles and the most common attitudes, this article will cast light on the challenges the community and the immigrants face in communicating with one another.

\section{Theoretical approach and data}

Now the migration processes have become of public and political significance, as well as the main government priority and the national security issue. Increase in migration flows is a challenge in the world today. This article updates the research perspective, concerning the relationship between host communities and immigrants. According to Coleman, the proportion of the foreignborn population in the European countries by the middle of the 21 st century could reach $30 \%$ of the total population (Coleman 2008).

The immigrant adaptation refers to the processes by which the newcomers adjust and integrate socially, economically, and politically within a new host community. The social scientists have long been interested 
in how immigrants are incorporated into new countries (Scott 1989; Heisler 1992; DeWind 1997; Hagan 1998; Portes et al. 2004; Mayblin 2016). In their attempts to understand the contemporary migration to industrialized nations the researchers focus increasingly on the concept of social connections in a multicultural context. The terms such as assimilation, acculturation, incorporation, and integration have been used to describe various ways of newcomers' adjustment to and involvement within a nation's economy, political and social systems. The adaptation processes of the immigrants is studied within a multicultural approach (Heisler 1992; Toğușlu et al. 2014), acculturation (Berry 1997; Wimmer \& Soehl 2014) and assimilation theories (Piedra \& Engstrom 2009; Albarracín 2016). On the both sides of the Atlantic, the sociological literature points at the possible role of the culture in explaining ways of immigrant incorporation, including socioeconomic mobility, school success, and intermarriage (LeMay 2000; Suárez-Orozco 2000; Portes \& Rivas 2011). The factors such as ethnicity, race, gender, education level, marketable skills, religious affiliation, and language competency may impact the ease with which the immigrants adjust to a new cultural and social system. The integrative threat theory explains the ways in which the host community responds to the newcomers, including the competition for the resources, negative stereotypes, fear and incompatibility of the cultural values (Stephen \& Stephen 1996; Tartakovsky et al. 2015).

The modern social and cultural processes caused by migration in the European community demonstrate the "historical reversal of the trend": a turn from mobility within the EU to the reception of other cultures (Mikhailova \& Verpatova 2016). Europe is becoming a more and more attractive destination for the immigrants. This updates the issue of not stopping people from coming, but how better to accept them for creating a harmonious community. The decision process is accompanied by the considerable challenges. It highlights the issue of "meeting" different cultural and social principles, relationships of interpenetrating territorial allegiance and migration. In the context of rethinking "global-local" trends researchers of cultural philosophy reassess the current cultural dialogue policy, which was established in the past half century. The economists and sociologists consider the migration influence on the human potential development in the European countries. The researchers point to strengthening social contradictions arising from migration in Europe, among which are the following: economic, political, cultural values, and religious contradictions (Sarrazin 2010; Kim 2013; Gubman 2016).

The researchers define 4 models of hostnation reactions to immigrants. These are total exclusion, differential exclusion (segregation), assimilation and pluralism. The 4 basic models of adaptive strategies used by immigrants are passive autarchy, aggressive autarchy, assimilation, integration (Saukkonen 2013). The ineffectiveness of assimilation policies led to the introduction of multiculturalism, which harmonized European society by creating the new realities in the relationships between the natives and the new Europeans (Kim 2013). The EU holds a pluralistic model that allows immigrants to form communities on ethnic principle, speak their mother language and preserve native culture. Actually, there are two kinds of pluralism - noninterference and multiculturalism. The noninterference permits the existence of cultural diversity, but the state does not provide any support for ethnic cultures. The multicultural policy implies the willingness of the majority of society to accept the cultural difference and readiness to change the social behavior in the community and even the social structures. As early as in 1936 Redfield, Linton, and Herskovits stated "acculturation comprehends those phenomena which result when groups of individuals having different cultures come into continuous first-hand contact with subsequent changes in the original cultural patterns of either or both groups" (Redfield et al. 1936). On the one hand, the immigrants should learn the language, history and tra- 
ditions of the host society, and on the other hand, the host community should be ready to accept immigrants. Under the multiculturalism, citizenship and legalization of the immigrant's status prevents the formation of enclaves and accelerates the integration of immigrants into the host community. Conversely, the temporary illegal status of the immigrants hinders their integration, and creates the danger of marginalization and formation of hostile subcultures. In case a person enters another social environment, the speed of his/her integration directly depends on the proximity of his/her cultural values to those adopted in the host community. The sociological researchers introduce three main patterns of immigrants' behavior in the new city environment (Karanov 2013):

1. An immigrant follows the rules of behavior and cultural norms specific to the new place of residence, identifying themselves with the relevant social environment. Finally, it leads to a gradual assimilation of migrants.

2. An immigrant identifies himself/herself with a specific settlement, but not its community, remaining faithful to the socio-cultural norms of the native community.

3. Feeling alienated and unwilling to adapt to a new socio-cultural environment, the immigrant leaves it.

The nature of the relationship with immigrants is often determined by local community expectations. Among the most common expectations are economic threats, physical security, cultural security, intergroup anxiety and negative stereotypes (Ryabichenko \& Lebedeva 2014; Wekhian 2016). The contradictions associated with the acceptance or rejection of a new culture by immigrants or representatives of the host community are of particular importance. The division of people into "we" and "they" in terms of human mobility intensification and uncontrolled migration policy demonstrates the failure of the "melting pot" of multiculturalism. These realities are transforming the state into a multicultural community with an unstable system of cross-cultural interactions where the har- monious contacts gradually become an utopia for fomenting conflict between host community and immigrants (Pine 2014; Boyko 2014). Among the factors influencing the adoption of a new culture, the researchers distinguish: duration of stay within a country, personal experience, age, the degree of similarity or differences in cultures, stereotypes, and intermarriages (Jaakkola 2009; Baturina 2016; Wekhian 2016).

At the beginning people tend to feel mercy and compassion providing the asylum seekers with the sufficient means of support and care. Local residents often have a positive attitude to migrants, without reference to their nationality, when migrants are resettled in the different parts of the city (Saukkonen 2013). Conversely, the members of the host community demonstrate alienation when immigrants are spatially separated because of their ethnic origins. According to the study of the Finnish attitudes towards migrants, they are varied locally. For instance, in 2007, in Vantaa, one of Finland's five biggest cities, exceptionally negative attitudes towards refugees, exist, though people were more favourable towards the foreign work applicants and the refugees in Helsinki, Turku and Tampere than in the countryside and the smaller cities (Jaakkola 2009).

The people moving to a new state or city face a completely new reality. Children tend to experience the acculturation process far more easily than adults (Barkan 2006; Glick 2010; Wekhian 2016). They integrate faster, finding common language with the counterparts and imitating the behavior. It is important to train friendly attitudes in children towards the other cultures and induce the readiness to discuss the problem situations starting in kindergarten, and then at school. It is the best way to avoid forming and consolidating negative stereotypes. However, some scholars argue that the level of acculturation among children depends on family traditions as well (Portes \& Rivas 2011; Ibrahim \& Cass 2011).

The cultural factors and language play a primary role in relations between the immi- 
grants, the host community and the successful acculturation. The success of the individual integration into a new social and cultural environment largely depends on the person. The main problem faced by the newcomers is a lack of social language knowledge: norms and rules of behavior. The compliance with group rules gives a person reason to consider himself/herself a part of it, depriving the other group members of the chance to refute this. The set of cultural values and appropriate community behavior settings can be defined as a social and cultural core, which is close to the concept of "guiding culture", argued for by the German-Arab sociologist Bassam Tibi (Tibi 1998). The group identity codes play a crucial role in the interaction of representatives of the various socio-cultural environments. Generally, the closer cultural points are, the easier the communication is. There are drastic cultural differences in non-verbal communication, relationships, values and standards of behavior and rituals and they often lead to unpleasant misunderstanding among nationalities. One of the most important characteristics that affect the efficiency of communication is a sensitivity of culture, namely receptivity and sensitivity to impacts on both the host state and immigrants. It provides the cultural sensitivity of perception, understanding, reproduction and interpretation of cultural features. According to Bennett M.J., intercultural communication, and crosscultural sensitiveness can be defined as "construction of reality, more and more capable of reconciling cultural differences that make up the development" (Logashenko 2015). Thus, "culture shock" which implies an emotional or physical discomfort in contact with another culture (the term used by American anthropologist Kalervo Oberg), a loss of a sense of security, and an identity crisis (Shaikhislamov et al. 2013) are experienced by both sides. Overcoming the culture shock reveals the possibility of a constructive intercultural interaction and dialogue, and mutual openings of cultural uniqueness. Otherwise, it leads to the aggravation of the contradictions and tensions (Solodova \& Gomzova 2013).
One of the ways to resolve the culture shock is represented by "partial assimilation", which includes the process of eliminating a number of traditions and beliefs of their culture for the purpose of initiation to the "cultural environment" (Konoplyova 2016).

We reviewed the extant literature showing that the interrelations of the local community and newcomers face lots of obstacles and depend on many factors. Mainly, a lack of knowledge in social norms and behavior patterns contribute to the disintegration processes, increasing the distance between newcomers and the local population. This leads to the emergence of marginalized groups. Further the levels of social inclusion and positive connection between people with the different backgrounds, life experiences and expectations can be achieved through the changes in communication with each other. Based on these premises, we propose that the communication activities with an accent on mutual learning and recognition, can help the immigrants and the locals establish social connections, which results in a more integrated society.

\section{Data analysis}

The article is based on the sociological research conducted in August to September, 2016 in Tornio (Finland) in the framework of the "Barents Movement" project. The project provides the art-science cooperation between Karelian (Russia) and Lapland (Finland) artists and researchers for the studying intercultural dialogue and investigating immigration and multiculturalism in the context of contemporary culture, transnational identities and cultural heritage.

In recent decades the dimensions of migration flows to Finland have changed dramatically. In 2004, the number of immigrants to Finland was 20,333 with the main immigration flow (70\%) from Europe (Sweden - 17.6\%, Russia - 9.9\%, and Estonia - 9.1\%) (Edvardsson 2007). According to the data provided by the Finnish Immigration Service (Decisions 2016) in the years 2015 and 2016 there is 
considerable shift in the number of residence permits applications from Africa and the Middle East countries (Tab. 1) had a population of about 22,000 people and hosted 289 asylum seekers and 32 immigrants(Fig. 1). Over the course of the research,

Table 1. Number of applications concerning residence permits and decisions made by the Finnish Immigration Service

\begin{tabular}{|c|c|c|c|c|c|c|c|c|c|}
\hline \multirow{2}{*}{ Rate } & \multirow{2}{*}{ Country } & \multicolumn{3}{|c|}{2015} & \multirow{2}{*}{ Rate } & \multirow{2}{*}{ Country } & \multicolumn{3}{|c|}{2016} \\
\hline & & In total & {$[\%]$} & positive & & & In total & {$[\%]$} & positive \\
\hline 1 & Russian Federation & 13,404 & 15.0 & 12,441 & 1 & Iraq & 19,581 & 17.8 & 5,184 \\
\hline 2 & Iraq & 6,527 & 7.3 & 2,940 & 2 & Russian Federation & 13,454 & 12.2 & 12,525 \\
\hline 3 & Estonia & 4,967 & 5.6 & 4,563 & 3 & Afghanistan & 7,110 & 6.5 & 3,430 \\
\hline 6 & Somalia & 4,143 & 4.6 & 3,190 & 4 & Somalia & 4,992 & 4.5 & 2,966 \\
\hline
\end{tabular}

The research interest raises questions of the formation and change in the social and cultural environment of the territory during the time of immigrants' inflow. Tornio was chosen as a research platform for the consideration of the various evidence of the multicultural identity. The research tasks were to define:

- the initial expectations and perceptions of the immigrants and the host community;

- the social and cultural practices of interaction between the locals and the newcomers in Tornio;

- positive (uniting, creating climate of tolerance) and negative (dividing) tendencies in society during an immigrants adaptation period.

The methodology used in our research was fundamentally qualitative. We sought to explore and unpack the meanings that participants (newcomers and locals) gave to their experiences when they interact with each other. In order to track and establish the patterns regarding these shared meanings, the following qualitative methods were used: the participant observation; the statistical analysis of the migration flows; the discourse analysis of the written sources; the questionnaires on city attractiveness, the interviews with the asylum seekers and the insiders views.

According to the data provided by Social Department of Tornio City, in 2016 Tornio we documented the life histories and narratives of 12 asylum seekers, whom we met at the Finnish Red Cross clubs and the Reception Center. Thus, the empirical data used in this paper is a set of 12 deep interviews, questionnaires on city Tornio attractiveness (73 locals) and human mobility challenges (89 locals). The interviews were conducted in English and questionnaires in Finnish and English languages.

\section{Tornio residents' opinion on the attractiveness of the city for the living and working (August, 2016)}

The respondents belong to the different socio-economic spheres in Tornio such as the City of Tornio, the Finnish-Russian society of Tornio, Lapland University of Applied Sciences, Vocational College Lappia, Tornio City Cultural Office, different museums and small shops, hairdressing saloons, cafes and others.

The sample consisted of 73 respondents - 52 women (71\%) and 21 men (29\%). The age of the largest group of respondents is 17-27 years (Table 2.). The eldest survey respondents are presented by the students (17-18 years old) of the Vocational College Lappia where they get an upper secondary vocational qualification in the field of their study programme. 


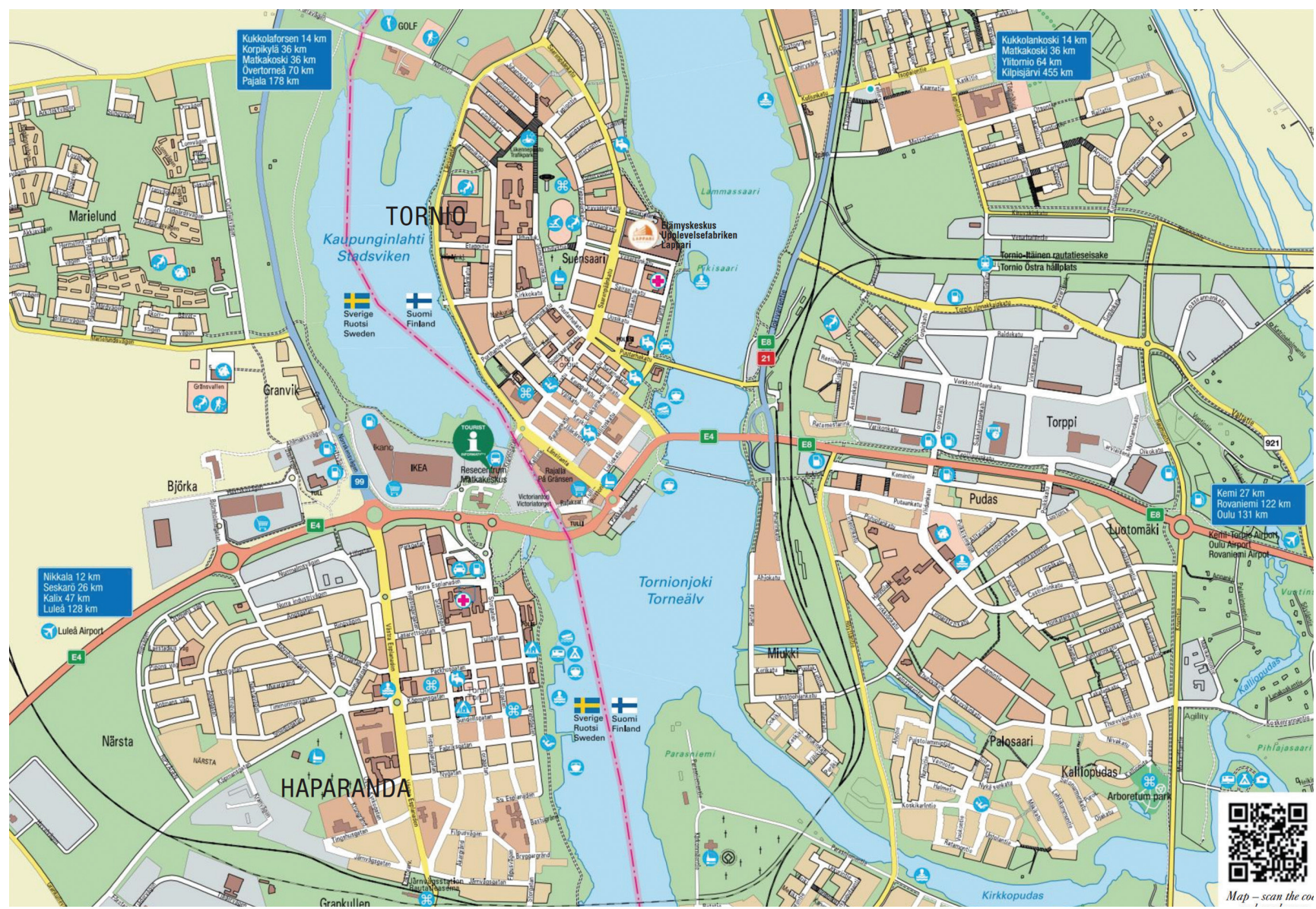

Figure 1. Map of Tornio City Center (Haparanda-Tornio, 2015) with marked objects:

1. Shopping center "Rajalla"; 2. Tornio Reception Center; 3. Finnish Red Cross Tornio; 4. Perheiden Talo 
Table 2. The age structure of respondents

\begin{tabular}{|c|c|c|c|}
\hline No & $\begin{array}{c}\text { Age of re- } \\
\text { spondents }\end{array}$ & $\begin{array}{c}\text { Amount of } \\
\text { respondents, } \\
\text { people }\end{array}$ & $\begin{array}{c}\text { Share of } \\
\text { respondents } \\
{[\%]}\end{array}$ \\
\hline 1 & $17-27$ & 18 & 24.7 \\
3 & $28-38$ & 16 & 21.9 \\
4 & $39-49$ & 15 & 20.5 \\
5 & $50-60$ & 13 & 17.8 \\
& $61-71$ & 11 & 15.1 \\
total & 73 & 100.0 \\
\hline
\end{tabular}

One of the research questions allows the definition of the opinion of the locals about Tornio as a favorable city for the living and work (Tab. 3). According to the empirical data the majority of locals (92\%) consider Tornio a favorable place for the living. The share of respondents is shown according to their sex.

The most popular explanations of Tornio as favorable city for the living are: the small and beautiful town (48.5\% of residents), the peaceful town (28\%), a lot of activities (25\%) and the border town (10\%). $80 \%$ of the residents consider that Tornio has good opportunities and is a favorable city for work. In support of this, locals mention jobs options (17.6\% of residents), border opportunities for two countries (10.3\%) and possibilities for education.
One of the key questions that allows us to understand the locals perception of the city is a question about change of living place. According to the empirical data about $70 \%$ of locals have no plans or have no certain plan to change the place of living (city Tornio).

\section{Tornio residents' opinion about asylum seekers (September, 2016)}

The spring opinion poll consisted of 5 questions and included 89 respondents - 55 women (62\%) and 34 men (38\%). The shopping center "Rajalla" ("On the border") was chosen for sociological research as the most likely place to find people. Table 4 demonstrates the opinion of the locals about asylum seekers.

The first question was devoted to relations towards the asylum seekers among the locals. It demonstrates that women notice more changes than men on the arrival of asylum seekers. The following answers were provided: the appearance of the new cultures ( $21 \%$ of respondents), the noisier streets (11\%) and lots of Arabic men (6\%). Some respondents spoke of the newly opened ethnic shops (3\%) and the Eastern Food Festival (2\%).

Generally the residents showed a neutral or positive attitude towards the asylum seekers. However, several men reacted negatively.

Table 3. The opinion of the locals about Tornio as a favorable city for living and working

\begin{tabular}{|c|c|c|c|c|c|}
\hline No & Questions & Answers & Women [\%] & Men [\%] & Total [\%] \\
\hline \multirow{4}{*}{1} & \multirow{4}{*}{$\begin{array}{l}\text { Is Tornio city favorable } \\
\text { for living? }\end{array}$} & yes & 92.4 & 90.4 & 91.8 \\
\hline & & no & 3.8 & 4.8 & 4.1 \\
\hline & & difficult to say & 3.8 & 4.8 & 4.1 \\
\hline & & Total [\%] & 100.0 & 100.0 & 100.0 \\
\hline \multirow{5}{*}{2} & \multirow{5}{*}{$\begin{array}{l}\text { Do you want to change } \\
\text { place of living (city Tornio)? }\end{array}$} & no plans & 48.1 & 76.2 & 56.2 \\
\hline & & $\begin{array}{l}\text { I think to change, but so far there are } \\
\text { no certain plans }\end{array}$ & 17.3 & 0 & 12.3 \\
\hline & & I plan to move & 17.3 & 9.5 & 15.1 \\
\hline & & difficult to say & 17.3 & 14.3 & 16.4 \\
\hline & & Total [\%] & 100.0 & 100.0 & 100.0 \\
\hline
\end{tabular}


Table 4. The opinion of the locals about asylum seekers

\begin{tabular}{|c|c|c|c|c|c|}
\hline No & Questions & Answers & Women [\%] & Men [\%] & Total [\%] \\
\hline \multirow{4}{*}{1} & \multirow{4}{*}{$\begin{array}{l}\text { Has the city image changed with } \\
\text { the arrival of asylum seekers? }\end{array}$} & yes & 70.9 & 50.0 & 62.9 \\
\hline & & no & 27.3 & 44.1 & 33.7 \\
\hline & & don't know & 1.8 & 5.9 & 3.4 \\
\hline & & Total [\%] & 100.0 & 100.0 & 100.0 \\
\hline \multirow{4}{*}{2} & \multirow{4}{*}{$\begin{array}{l}\text { What is your attitude to asylum } \\
\text { seekers? }\end{array}$} & positive & 55.5 & 29.4 & 44.94 \\
\hline & & negative & 5.5 & 17.7 & 10.2 \\
\hline & & neutral & 40.0 & 52.9 & 44.94 \\
\hline & & Total [\%] & 100.0 & 100.0 & 100.0 \\
\hline \multirow{6}{*}{3} & \multirow{6}{*}{$\begin{array}{l}\text { How do you communicate with } \\
\text { asylum seekers? }\end{array}$} & no communication & 14.6 & 52.9 & 29.2 \\
\hline & & seldom & 38.2 & 20.5 & 31.5 \\
\hline & & We are friends & 23.6 & 5.9 & 16.9 \\
\hline & & I try to avoid communication & 20.0 & 20.6 & 20.2 \\
\hline & & I had conflict & 3.6 & 0 & 2.2 \\
\hline & & Total [\%] & 100.0 & 100.0 & 100.0 \\
\hline \multirow{3}{*}{4} & \multirow{3}{*}{$\begin{array}{l}\text { Are you ready to help asylum } \\
\text { seekers? }\end{array}$} & yes & 85.5 & 67.6 & 78.7 \\
\hline & & no & 14.5 & 32.4 & 21.3 \\
\hline & & Total [\%] & 100.0 & 100.0 & 100.0 \\
\hline \multirow{4}{*}{5} & \multirow{4}{*}{$\begin{array}{l}\text { Do you believe that immi- } \\
\text { grants should have the same } \\
\text { rights as citizens? }\end{array}$} & yes & 90.9 & 58.8 & 78.7 \\
\hline & & no & 9.1 & 35.3 & 19.1 \\
\hline & & don't know & 0.0 & 5.9 & 2.2 \\
\hline & & Total [\%] & 100.0 & 100.0 & 100.0 \\
\hline
\end{tabular}

Some others made remarks that the refugees are a burden to the society because they take many social benefits that would otherwise be available to the citizens.

The women (38\%) more often than men (20\%) communicated with the asylum seekers and even $17 \%$ made friends. There were four volunteers from the Finnish Red Cross among respondents. There were people who reacted negatively and emphasized that they avoid the communication, 11 women and 7 men. Two women told about the conflicts: the shop assistant stopped theft and another woman had a quarrel on the playground. Generally, females provide more interpersonal support than males.

The majority of women and men (79\%) are ready to help the asylum seekers. According to the answers given by the people of Tornio, they helped with household goods (21\%), advice (18\%) and even money (9\%) when asylum seekers arrived. The answer "help with advice" testifies that quite a large number of residents is ready for communicating with newcomers. However, 21\% of residents are not eager to render assistance to newcomers, mentioning that the government already helps or it's the duty of the municipality to support them.

One of the most important questions was devoted to the equal rights of immigrants and citizens. The majority of women and men (79\%) believe that immigrants should have equal rights with citizens. At the same time respondents add that immigrants should learn language (72\%), understand culture 
(60\%), find a job (38\%), obey the laws (13\%), pay taxes (11\%), and look like European (1\%). However there are more negative answers among men, who consider that immigrants will never become equal and they should return home ( $13 \%$ of men).

\section{Tornio asylum seekers' opinion about the city and its people (September, 2016)}

The task of the project was to determine the perceptions of the asylum seekers towards the new place of living. The key questions of the interview were agreed with specialists of the Reception Center and the Finnish Red Cross clubs. The respondents gave their consent to the interview and were informed that materials would be published. The interviews were carried out individually at the office of the Reception Center and consisted of open questions in which interviewees were asked about why Finland and Tornio were chosen, with whom they communicated, what challenges they faced, what traditions followed and plans for the future. All interviews were held in English, audio recorded and lasted between 30 minutes and an hour.

The twelve representatives of Nigeria, Iraq and Afghanistan took part in the interviews. Those who arrived in Tornio in September 2015 are accommodated in the Reception Centers across Finland until the confirmation of the real threat to their lives at home and getting a "refugee" document. According to the Finnish data, about 20,000 asylum seekers from various countries didn't receive any decision on their status in 2015 (Population... 2017). In 2016 the Finnish Immigration Service issued 14,282 negative decisions on asylum applications (Population... 2017). The process of acculturation can be particularly stressful and destructive, for instance, refusal and an age test might be risk factors for the mental health of asylum seekers (Bunikowski 2016). Men are refused more often than women, because they can leave for safer areas within their native country. Many still stay in Finland, since the Finnish side has no formal agreement with Iraq for the return of refugees. According to the Central Criminal Police, about 2,500 asylum seekers, who arrived to Finland, disappeared (Bunikowski 2016).

According to the data provided by Social Department of Tornio City, the average newcomer is a 30 to 40 year old man. It's very common that the immigrants do not have any certificate of education. Most of the women have been housewives and men have been working in construction, metal industry, or as farmers and chauffeurs. Unlike the immigrants, the asylum seekers have no permission to work, their children do not attend school or kindergarten, and they are given fewer hours of language courses. Because of the unemployment they have a lot of free time and little alternatives to do.

"I am bored here. I can't get job and can't move to the Helsinki camp where my friends live. The city is small, silent and there is no place to go." (Man, 25 years old, Iraq).

"I feel safety and care here, openness and warmth from people, but I feel like an alien outside. I mostly communicate on Facebook with my relatives and friends in Iraq or other Finnish camps." (Man, 23 years old, Iraq).

"We (Authors' note - newcomers and locals) look at each other as strangers. We don't communicate. I speak English, but I don't dare communicate with locals. I am willing to tell my story and learn about the place, but only journalists and authorities are interested in them." (Man, 31 years old, Iraq).

"From the locals' view, we remain immigrants, low-status persons who are tolerated rather than wanted." (Man, 48 years old, Afghanistan).

During the interviews, it was found that, in addition to belonging to the national community, respondents in most cases emphasize their connection with ethnic groups (e.g. Kurds from northern Iraq). Besides, in order to avoid conflicts in the Reception Center, they are settled within their ethnic groups. Practice shows that temporary settlements of immigrants attract more and more compatriots, growing and turning into ethnic enclaves. The newcomers feel longing for the native country 
thus communicating more often with the representatives of their culture, rather than with the people of the host country. As a result, the segments of professions are often, closely associated with a particular ethnic group. According to the interviews with the asylum seekers, in Tornio all owners of pizzerias are immigrants from Turkey. Due to the lack of social ties with the locals it can turn into the segregation of immigrant settlements. These are often characterized by a weaker economic situation that also causes the marginalization of newcomers, resulting in a risk of poverty or social exclusion (Migration and the EU 2016). This influences the transformation of the social relations from a good neighborhood to a rapidly developing conflict.

From the interviews it was revealed that waiting on a decision for one year badly affected the mood of the people, many suspended language courses, felt depressed, disliked the climate, due to long winters and the lack of warmth and sun.

"The climate is awful, it's too cold, there's no normal tea, no restaurants, no bars, nobody on the streets, only cars." (Man, 22 years old, Iraq).

"My children have problems with their health, because of the cold winter." (Man, 25 years old, Iraq).

"I was inspired at the beginning. We paid 8,000 Euros to get here and on the Internet the place seemed nicer. The language is so difficult. I don't know what to do if I get a negative decision." (Woman, 52 years old, Iraq).

The Tornio Reception Center is a thirty minutes walk from the city center. The "Rajalla" shopping centre is the most visited place by asylum seekers. They go there to spend time, often staying in groups, talking to each other. It seems a tool for compensating their alienation. Refugees retain traditions in cooking national cuisine, clothing and musical preferences. They are not used to Finnish or European food, consequently, immigrants have opened ethnic shops with Arab goods, mainly food (rice, coffee, tea, sweets) in Tornio. However, some newcomers believe they should assimilate:
"We left our country and we should leave our culture there and learn day by day European rules. I like the life here. People respect others, all religions. Education is free for all, the country is clean. The culture differs and we don't know the society. Everything is different." (Woman, 29 years old, Iraq).

"I want a good life for my daughter, she will never return to Nigeria. My parents gave me up after I got pregnant. I ran to Spain, then to Finland. There are good social conditions and benefits." (Woman, 28 years old, Nigeria).

"Our country is destroyed. I was running to save the lives of my daughters, while my husband is still in Iraq. Here we see another attitude to people and women. My daughters will be happier here." (Woman, 52 years old, Iraq).

At the beginning the people of Tornio helped newcomers with household appliances, clothes and even money, but newcomers' reaction to the reception conditions (because of tighter policies, smaller stipends and swifter returns) transformed residents' attitude towards newcomers. A number of antimigrant demonstrations took place in Tornio, including some arson attacks on the Reception Center (Tanner 2016).

Comparison of target groups' answers identified social and cultural practices of interactions among newcomers and locals. A newcomer deals with lots of confusion, not understanding spoken and unspoken values and rules of the new country. Asylum seekers soon find that life in Finland is far more difficult than they anticipated. They have been drawn into another role tied to a different set of assumptions about gender, kinship, race, and economy.

"I had a problem with my family, because of a pre-marital relationship. However, making friends with the locals is not always easy because the locals already have friends." (Woman, 29 years old, Iraq).

If immigrants want to feel empathy, being heard and understood because of the need to fit in society, locals by contrast experience the pressure of giving space to new people, and accommodating their habits and ways of life. It was indicated that refugees have a lack of information about city events and 
don't know about activities in which they can take part. The Finnish Red Cross club is the place (cultural platform) that attracts immigrants who learn the language through cooking, knitting and talking. The social center "Perheiden Talo" (Family House) is another platform for different kinds of the activities with the immigrants, mainly children and female immigrants. There are very trusting and friendly relations between the Red Cross volunteers and immigrants. Such cultural meetings allow people to learn the rules of behavior and cultural norms that are typical for the new place of residence.

The Reception Center staff regularly organizes movies, sport activities, but the number of participants in such events is not high. In particular the young people consider the opportunity of moving to big cities like Helsinki, Tampere and Turku. They show the alienation and the unwillingness to adapt to the new social and cultural environment. The social work director of City of Tornio noted that the city did not have enough activities to unite the urban community and immigrants. Only by communicating their intentions and meeting with others, will people try to understand, to change or to adapt. The thought is that by knowing each other, the newcomers and the locals will be less afraid of one another and open to embracing the novelty. A process of learning general and socio-cultural norms occurs only when an individual is in constant interaction with other community members (Wang et al. 2015).

\section{Conclusions}

Our study has some limitations. The results are based on the deep interviews with the asylum seekers with a majority from Iraq and questionnaires of the locals on Tornio's attractiveness. The selection of interviewees was limited by the ignorance of English language and unwillingness to take part in the interview. Therefore, our results may not be generalized to other host communities and to the different groups of the asylum seekers. Despite these limitations, the study offers understanding of the newcomers' integration into the local culture, understanding of the parties' perceptions of each other in reality.

In general, the study found out that border city Tornio was not a destination for the asylum seekers, but a crossing point to get to Finland and Europe. The ignorance of European culture and Eastern culture leads to misunderstanding between two parties (locals and newcomers) as well as confrontation of expectations and reality. As a result, the newcomers identify themselves with a particular territory (Tornio City), but not its community. They continue to follow the national traditions, the eating patterns, keeping the musical preferences that will probably lead to the formation of the expatriate communities and diasporas. The refusal to legalize the newcomer status endangers their marginalization and the formation of hostile subcultures. These characteristics stand for the passive autarchy model when the migrants avoid the direct contacts with the foreign culture and eliminate the negative symptoms of the cultural shock (Karanov 2013; Saukkonen 2013).

The residents of the border city of Tornio are quite open and tolerant to representatives of different cultures. Although the men and older generation show a negative attitude towards immigrants, in general, city residents are quite friendly and open-minded in regard to newcomers. However, the intercultural differences are visible in basic values: humanism, justice, individualism, respect for minority rights for Europeans, traditionalism and collectivism - for asylum seekers.

According to the so-called Contact Theory, the most efficient way of reducing prejudices between ethnic groups is to increase encounters between them (Jaakkola 2009). Summarizing the opinions of the asylum seekers, representatives of the Reception Center and the Finnish Red Cross Tornio, the joint cultural activities are necessary for the improving the overall cross-cultural and inter-ethnic communication in the city. The organization of the meetings, discussion clubs, language courses may provide not only linguistic and vocational training for the newcomers, but familiar- 
ity with everyday culture, system of values, way of thinking for different age and professional groups. The recognition of the diversity of cultures, understanding general principles of another culture and the use of relevant cultural codes may prevent extreme forms, such as ethnocentrism, xenophobia, structural discrimination on ethnic grounds.

\section{Acknowledgments}

We express our gratitude towards Maria Dyakonova (Institute of Economics KarRC of RAS), Marika Kurth (Finnish Red Cross, Tornio Reception center for asylum seekers), Malla Alatalo (Art Promotion Center Finland) for the fruitful collaboration as well as to the

\section{References}

AlbaRRACín J., 2016. The culture of incorporation: Language use, identity, and social connectedness [in:] At the core and in the margins: Incorporation of Mexican immigrants in two rural midwestern communities, East Lansing: Michigan State University Press, pp. 29-48.

AnNuAl Report 2015. The Finnish Immigration Service, http://migri.fi/documents/5202425/67721 75/2015\%20Annual\%20Report/d376b6c83551-4865-be6b-432b67bc4c6d [30 March 2018].

Asylum SEEKER TRAFFIC DRIES UP AT LAPLAND BORDER CROSSINGS. YLE Uutiset, 28 June 2016, https:// yle.fi/uutiset/osasto/news/asylum_seeker_ traffic_dries_up_at_lapland_border_crossings/8987641 [30 March 2018].

BARKAN E., 2006. Immigration, incorporation, assimilation, and the limits of transnationalism: Introduction. Journal of American Ethnic History, vol. 25, no 2-3, pp. 7-32.

BATURINA L., 2016. Problems of migrants adapting to a new culture [in:] Language and thought: Psychological and linguistic aspects, Articles of XVI International Scientific Conference, pp. $70-75$ [in Russian].

BERRY J.W., 1997. Immigration, acculturation, and adaptation. Applied Psychology: An International Review, vol. 46, pp. 5-34.
Finnish Red Cross volunteers and storytellers who helped us during the research activities in 2016. We also thank Juha Fränti (Tornio City Social Department) for his statistical advice, Helena Junes (Tornio City Cultural Office) and Elena Kaukonen (Tornio Finnish-Russian Society) for the help in conducting sociological surveys. Special thanks to Stephen G F Hall, $\mathrm{PhD}$ candidate at University College London (UCL) and John Dawton (LVC, London School of English) for thorough language review of the text. This publication is a part of the research works conducted at the Institute of Economics of the Karelian Research Center of the Russian Academy of Sciences that was supported by the Ministry of Education and Culture of Finland as well as European Cultural Foundation.

BoYko A., 2014. Deviation in the context of modern migration processes [in:] Materials of 8th All-Russian scientific and practical conference with international participation, December 5, 2014, Krasnodar [in Russian]

BUNIKOWSKI D. 2016. Finland's immigration crisis. Gatestone Institute, https://www.gatestoneinstitute.org/7559/finland-migrant-crisis [12 November 2017].

Coleman D., 2008. The demographic effects of international migration in Europe. Oxford Review of Economic Policy, vol. 24, no. 3, pp. $452-476$

DECISIONS 1/2015-12/2016. Finnish Immigration Service. http://statistics.migri.fi/\#decisions? start $=540$ \&end $=551$ [12 November 2017].

DEWIND J., KASINITZ P., 1997. Everything old is new again? Processes and theories of immigrant incorporation. The International Migration Review, vol. 31, no. 4, pp. 1096-1111.

EĐvaresson I.R., Heikkilä E., Johansson M., Jóhannesson H., Rauhut D., SChmidt T.D., Stambøl L.S., WiLKman S., 2007. Demographic changes, labour migration and EU-enlargement - relevance for the Nordic regions. Nordic Research Programme 2005-2008, Report 2, Stockholm: Nordregio.

EMN, 2017. Key figures on immigration 2016. Helsinki: European Migration Network Finnish Immigration Service. 
GLICK J., 2010. Connecting complex processes: A decade of research on immigrant families. Journal of Marriage and Family, vol. 72, no. 3, pp. 498-515.

GuBMAN B., 2016. Dialogue in view of post-classical Philosophy. Culture of Culture, vol. 9, no. 1, pp. 100-107.

Hagan J.M., 1998. Social networks, gender, and immigrant incorporation: Resources and constraints, American Sociological Review, vol. 63, no. 3, pp. 55-67.

Haparanda-Tornio, 2015. Haparanda Tornio: Borderless experiences all year round. Easy and fun to cross the border. https://issuu.com/ haparandatornio/docs/haparandatornio_broschure_2017 [17 June 2018].

HeIsleR B., 1992. The future of immigrant incorporation: Which models? Which concepts? The International Migration Review, vol. 26, no. 2, pp. 623-645.

IBRAHIM F.A., CASS D., 2011. Counseling Muslim Americans: Cultural and spiritual assessments. Journal of Counseling and Development, vol. 89, no. 4, pp. 387-397.

JAAKKOLA M., 2009. Immigrants from a Finnish point of view. Attitudes changes over 1987-2007. Helsingin kaupungin tietokeskus (Helsinki, Finland: City of Helsinki Information Centre).

JOPPKE C., 2012. The role of the state in cultural integration: Trends, challenges, and ways ahead. Washington DC: Migration Policy Institute.

KaRANOV D., 2013. Migrants and the host community: The cultural aspect of interethnic relations in the urban environment. Politeia, vol. 68, no. 1 , pp. 24-35 [in Russian].

KIM V., 2013. Social contradictions in the "mirror" of migration as a factor in the emergence of fanaticism. Annals of Tomsk State Pedagogical University, vol. 133, no. 5, pp. 122-128 [in Russian].

Konoplyova A., 2016. Understanding the process of the phenomenon of cultural shock in the context of modern migration processes. SocialHumanitarian Review, vol. 1, pp. 41-43 [in Russian].

LeMay M., 2000. Assessing assimilation: Cultural and political integration of immigrants and their descendants. In Defense of the Alien, vol. 23, pp. 163-176.
LOGASHENKO JU.A., 2015. Intercultural sensitivity of students in the multicultural environment. Saint-Petersburg [PhD Thesis], pp. 52-56 [in Russian].

LÖF R., 2016. The world will change with the influx of asylum seekers. Bulletin of University of Eastern Finland, pp. 12-16.

MAYBLIN L., 2016. Complexity reduction and policy consensus: Asylum seekers, the right to work, and the 'pull factor' thesis in the UK context. The British Journal of Politics and International Relations, vol. 18, no. 4, pp. 812-828.

Migration and the EU. Challenges, opportuniTIES, THE ROLE OF EIB, 2016. Report of the European Investment Bank. Luxembourg. March.

MIGRATION INTEGRATION STATISTICS - AT RISK OF POVERTY AND SOCIAL EXCLUSION. http://ec.europa.eu/ eurostat/statistics-explained/index.php/Migration_integration_statistics_-_at_risk_of_poverty_and_social_exclusion [12 November 2017].

Mikhailova E., Verpatova O., 2016. Discussion about the nature of social and cultural space in the works of Western theorists of the XX century: Rootedness and migration. Annals of the Tver State University. Series: Philosophy, no. 1, pp. 147-159 [in Russian].

Number of asylum applications IN FInLAND from 2015 TO 2016, BY COUNTRY OF ORIGIN. Statista: The statistics portal, https://www.statista. com/statistics/530300/asylum-applications-bycountry-of-origin-finland/ [30 March 2018].

NUMber of (NON-EU) ASYLUM SEEKERS IN THE EU and EFTA Member States, 2015 and 2016. Eurostat: Statistics explained, https:// ec.europa.eu/eurostat/statistics-explained/ index.php?title=File:Number_of_(non-EU)_asylum_seekers_in_the_EU_and_EFTA_Member_States,_2015_and_2016_(thousands_of_ first_time_applicants)_YB17.png [30 March 2018].

Piedra L., Engstrom D., 2009. Segmented assimilation theory and the life model: An integrated approach to understanding immigrants and their children. Social Work, vol. 54, no. 3, pp. 270-277.

PINE F., 2014. Migration as hope: Space, time, and imagining the future. Current Anthropology, Crisis, Value, and Hope: Rethinking the Economy, vol. 55, no. S9, pp. 95-104. 
Population. Statistics Finland, http://www.stat.fi/ tup/suoluk/suoluk_vaesto_en.html [30 March 2018].

Portes A., DeWInd J., 2004. A cross-Atlantic dialogue: The progress of research and theory in the study of international migration. The International Migration Review, vol. 38, no. 3, pp. 828-851.

Portes A., Rivas A., 2011. The adaptation of migrant children. The Future of Children, vol. 21, no. 1, pp. 219-246.

PRC, 2016. Europeans fear wave of refugees will mean more terrorism, fewer jobs. Pew Research Center. Global Attitudes \& Trends, 11 July, 2016, http://www.pewglobal.org/2016/07/11/ europeans-fear-wave-of-refugees-will-meanmore-terrorism-fewer-jobs/ [29 March 2018].

Redfield R., Linton R. Herskovits M., 1936. Memorandum for the study of acculturation. American Anthropologist New Series, vol. 38, no.1, pp. 149-152.

REGISTRATION CENTRE IN TORNIO UP AND RUNNING. Finnish Government, 22 September 2015, http://valtioneuvosto.fi/en/article/-/asset_publisher/1410869/tornion-jarjestelykeskuksentoiminta-kaynnistynyt [30 March 2018].

RyAbiChenKo T., LebedeVA N., 2014. Attitude to immigration and subjective well-being of the host population. Social Sciences and Modernity, no. 2, pp. 34-44 [in Russian].

SARRAZIN T., 2010. Deutschland schafft sich ab. Wie wir unser Land aufs Spiel setzen. München: Audio Media Verlag.

SAUKKONEN P., 2013. Multiculturalism and cultural policy in Northern Europe. Högskolan i borås, nordisk kulturpolitisk tidskrift, vol. 16, no. 2, pp. $178-200$

SCOTT W., 1989. Adaptation of immigrants: Individual differences and determinants. International Series in Experimental Social Psychology, Oxford, England; New York: Pergamon Press.

Shaikhislamov R., Varganova O., SadretdinoVA E., YULBARISOVA Y., 2013. Migration processes in the region: The problem of tolerance and dialogue between cultures. Annals of the East Academy on Economics and Law, vol. 64, no. 2, pp. 76-85 [in Russian].

Solodova G., Gomzova V., 2013. International migration - the host society and migrants of other nationalities. Siberian Philosophical Journal, vol. 11, no. 2, pp. 62-67 [in Russian].

Stephen W.G., Stephen C.W., 1996. An integrated threat theory of prejudice. International Journal of Psyhology, vol. 31, pp. 1635-1635.

SuÁrez-Orozco M., 2000. Everything you ever wanted to know about assimilation but were afraid to ask. Daedalus, vol. 129, no. 4, pp. 1-30.

TANNER A. Overwhelmed by refugee flows, Scandinavia tempers its warm welcome. http:// www.migrationpolicy.org/article/overwhelmedrefugee-flows-scandinavia-tempers-its-warmwelcome [12 November 2017].

TARTAKOVSY E., WALSH S.D., 2016. Testing a new theoretical model for attitudes toward immigrants: The case of social workers' attitudes toward asylum seekers. Journal of Cross-Cultural Psychology, vol. 47, no. 1, pp, 72-96.

TIBI B., 1998. Europa ohne Identität? Die Krise der multikulturellen Gesellschaft. München: Bertelsmann.

ToĞușlu E., Leman J., Sezgin i̇.M. (eds.), 2014. New multicultural identities in Europe: Religion and ethnicity in secular societies. Leuven: Leuven University Press.

Wang M., Kammeyer-Mueller J., Liv Y., Li Y., 2015. Context, socialization, and newcomer learning. Organizational Psychology Review, vol. 5, no. 1, pp. 3-25.

WeKHIAN J., 2016. Acculturation process of ArabMuslim immigrants in the United States. Asian Culture and History, vol. 8, no. 1, pp. 89-99.

Wimmer A., Soent T., 2014. Blocked acculturation: Cultural heterodoxy among Europe's immigrants. American Journal of Sociology, vol. 120, no. 1, pp. 146-186. 